Nuances of Indonesian Languages, 2020, Vol 1 ( No. 1), 48 - 60

DiterbitkanolehPPJB-SIP*

Tuti Wijayanti $^{1}$

\title{
Tindak Tutur Bahasa Indonesia Komunitas Prajurit TNI-AD Rindam XIV/ Hasanuddin Dilihat dari Fungsi Kalimat: Suatu Tinjauan Sosiopragmatik
}

\begin{abstract}
Abstrak
Penelitian ini membahas tindak tutur Bahasa Indonesia komunitas prajurit TNI-AD Rindam $\mathrm{XIV/Hasanuddin.} \mathrm{Tujuan} \mathrm{penelitian} \mathrm{untuk} \mathrm{mendeskripsikan} \mathrm{dan} \mathrm{menginterpretasikan} \mathrm{tindak} \mathrm{tutur}$ antara komunitas prajurit TNI-AD Rindam XIV/Hasanuddin dalam penggunaan Bahasa Indonesia dilihat dari fungsi kalimat secara umum tetapikenyataan di lapangan bahwa karakteristik berbahasa prajurit memiliki pola tertentu. Jenis penelitian ini adalah penelitian deskriptif analisis dengan menggunakan pendekatan kualitatif. Data dalam penelitian ini adalah ujaran yang di dalamnya terdapat fungsi kalimat yang muncul dalam tindak tutur antara komunitas prajurit TNIAD Rindam XIV/Hasanuddin. Sumber data dalam penelitian ini adalah prajurit TNI-AD Rindam XIV/Hasanuddin yang diambil sejumlah 18 orang. Pengumpulan data dalam penelitian ini dilakukan dengan menggunakan teknik perekaman. Analisis data penelitian dilakukan melalui model interaktif yang diperkenalkan oleh Miles dan Huberman. Teknik analisis data dilakukan secara kualitatif. Hasil penelitian menunjukkan bahwaKalimat deklaratif dalam tindak tutur antara komunitas prajurit TNI-AD Rindam XIV/Hasanuddin menuntut mitra tutur untuk memusatkan perhatian dari pembicara, pembicara juga mempunyai otoritas memberikan motivasi, dan nasihat karena kuatnya hierarki kepangkatan dan senioritas di dalam komunitas prajurit TNI tersebut seringkali ujaran tersebut sekaligus menuntut perlakuan, sehingga apa yang diucapkan sekaligus dibarengi dengan perbuatan. Hal ini menjadi sangat menarik, karena tidak semua komunitas sosial dapat melakukan hal tersebut. Kalimat interogatifterdapat indikasi yang sangat tidak baik berkaitan dengan disiplin dan loyalitas ketika kalimat interogatif ini tidak mampu menjembatani komunikasi yang baik.Kalimat imperatif menjadi hal yang tidak dapat ditawar dalam tuturan yang terbangun di komunitas prajurit TNI-AD karena tuturan yang berupa perintah menuntut prajurit untuk tunduk dan taat menjalankannya.
\end{abstract}

Kata kunci: tindak tutur, komunitas prajurit TNI-AD, fungsi kalimat,tinjauan sosiopragmatik;

doi:

Makalah diterima redaksi: 02, 02, 2020

Makalah disetujui untuk dipublikasikan: 11, 03, 2020

\footnotetext{
* PPJB-SIP: Perkumpulan Pengelola Jurnal Bahasa dan sastra Indonesia serta Pengajarannya

${ }^{1}$ E-mail : tutiwijyantikop9@gmail.com, STIA PRIMA Bone
} 


\section{Pendahuluan}

Tindak tutur atau speech act senantiasa melibatkan pembicara dan pendengar. Suatu tuturan tidak hanya digunakan untuk menyatakan suatu hal, tetapi dari tuturan seseorang dapat mengungkapkan sikap, perasaan, dan maksud penutur. Tindakan-tindakan yang ditampilkan lewat tuturan disebut tindak tutur, tindak tutur ini bisa berupa permintaan maaf, keluhan, pujian, undangan, janji atau permohonan. Aktivitas berkomunikasi pasti melibatkan tindak tutur, aktivitas berkomunikasi inilah yang menghasilkan tuturan. Oleh karena itu, tindak tutur harus sesuai dengan posisi penutur, situasi tutur, dan kemungkinan struktur yang ada dalam bahasa itu terbangun. Inilah yang dikatakan aktivitas bertutur itu tidak lepas dari konteks situasi. Sejalan yang disampaikan Alwasilah (1993:20) bahwa ujaran bersifat context dependent (tergantung konteks).

Yule (2006:102) menjelaskan bahwa sejumlah besar yang dikomunikasikan ditentukan oleh hubungan sosial. Interaksi linguistik pada dasarnya memerlukan interaksi sosial. Sejalan dengan Yule, Chaika (1989:3) menegaskan sosiolinguistik adalah telaah bahasa yang digunakan dalam masyarakat untuk berbagai macam interaksi sosial. Seperti pendapat Trudgill (1974:87) yang menjelaskan bahwa penutur yang sama dapat menggunakan variasi bahasa yang berbeda dalam situasi dan tujuan yang berbeda pula. Hal tersebut diperkuat pula oleh Labov (1972:188), sebuah bahasa mempunyai beberapa pilihan untuk mengatakan hal-hal yang sama.

Teori Labov menjelaskan bahwa terdapat hubungan antara sikap bahasa dan cara berbahasa kelompok sosial terhadap penggunaan bahasa dalam berinteraksi. Penelitian Labov ini menyimpulkan bahwa semakin tinggi kelas sosial masyarakat semakin baik penggunaan bahasanya. Kelompok sosial yang dimaksud Labov dalam penelitian tersebut adalah kelompok masyarakat yang memiliki kesamaan tertentu dalam bidang kemasyarakatan, seperti bidang ekonomi, pekerjaan (profesi), pendidikan, dan kedudukan. Kelompok sosial ini akan membentuk satu komunitas (Community) tertentu dalam satu lingkungan tertentu.

Sosiopragmatik dapat dikatakan telaah sosiologis pragmatis. Jadi, jelas di sini betapa erat hubungan antara sosiopragmatik dengan sosiologi (Tarigan, 1990:26).Sosiopragmatik yang telah dikelaskan Leech (1993) memiliki kesamaan dengan istilah yang oleh Michael Canale (1983) disebut dengan ketepatan isi (appropriateness in meaning), yaitu sejauh mana fungsi komunikasi tertentu, sikap dan gagasan dianggap tepat sesuai dengan situasi yang berlaku. Hal ini berhubungan erat dengan aspek sosiologi. Sebagai contoh, tidak tepat ketika berada dalam situasi sedih membicarakan hal yang bersifat gembira. Materi pembicaraan yang dibangun jelas tidak sesuai dengan konteks yang ada. Begitu juga ketika seseorang menyapa orang yang strata sosialnya lebih tinggi dengan sapaan yang biasanya disampaikan kepada seseorang yang setara atau malah di bawahnya. Hal ini jelas menunjukkan bahwa penggunaan bahasa itu tidak sesuai dengan situasi dan kondisinya. Jadi, jelas bahwa sosiopragmatik adalah telaah penggunaan bahasa yang sangat erat hubungannya dengan aspek sosial.

Sosiopragmatik selalu berkaitan dengan aspek sosial dan konteks. Oleh karena itu, di dalam kajian sosiopragmatik selain melibatkan tindak tutur sebagai bagian teori, pragmatik juga melibatkan peristiwa tutur. Peristiwa tutur menjadi penting dalam sosiopragmatik karena tuturan yang muncul selain dikaji dari aspek pragmatik pasti dilihat juga dari aspek speech event (peristiwa tutur), di mana dan kapan tuturan itu terjadi.Selain berhubungan erat dengan peristiwa tutur, sosiopragmatik juga melibatkan situasi tutur. Situasi tutur adalah situasi yang melahirkan tuturan. 
Di dalam komunikasi pasti berada dalam situasi tuur. Tuturan merupakan akibat, sedangkan situasi tutur merupakan sebabnya. Bermacam-macam tuturan dapat mengungkapkan sebuah maksud. Leech (dalam Wijana 1996), memetakan situasi tutur menjadi Lima komponen yaitu:

1. Penutur dan lawan tutur mencakup usia, latar belakang sosial ekonomi, jenis kelamin, tingkat keakraban, dsb.

2. Konteks tuturan mencakup, konteks dalam semua aspek fisikatau setting sosial dari tuturan yang bersangkutan.

3. Tujuan tuturan yang merupakan bentuk-bentuk tuturan yang diutarakan oleh penutur dilatarbelakangi oleh maksud dan tujuan tertentu.

4. Tuturan sebagai bentuk tindkan atau aktivitas yakni bahwa tindak tutur merupakan tindakan juga yang diperankan oleh alat ucap.

5. Tuturan sebagai pokok tindak verbal berupa tindak mengekspresikan kata-kata atau bahasa.

Kelima komponen itu menyusun suatu situasi tutur di dalam peristiwa tutur. Komponen lain yang juga dapat menjadi unsur situasi tutur adalah waktu dan tempat pada saat tuturan itu diproduksi. Tuturan yang sama dapat memiliki maksud yang berbeda akibat perbedaan waktu dan tempat sebagai latar tuturan. Hal tersebut berhubungan dengan bermacam-macam maksud yang mungkin dikomunikasikan oleh penutur di dalam sebuah tuturan.

Peristiwa tutur yang membangun tuturan dalm penelitian ini adalah tuturan yang dilakukan komunitas prajurit TNI-AD Rindam XIV/Hasanuddin baik di dalam ruangan maupun di luar ruangan. Tuturan yang terjadi dilakukan pada saat apel, rapat, dan aktivitas latihan di lapangan.

Setiap komunitas pasti mempunyai karakteristik bertutur yang membedakan komunitas tersebut. Di dalam istilah kebahasaan disebut dengan register. Begitu halnya yang terjadi di dalam komunitas prajurit TNI-AD Rindam XIV/Hasanuddin. Tindak tutur yang terbangun adalah tuturan yang terbentuk dari kalimat-kalimat yang sesuai dengan register komunitas tersebut. Seperti yang telah dipahami bahwa tuturan seseorang pasti melibatkan kalimat. Kalimat mempunyai beberapa fungsi untuk dapat mendukung makna yang diharapkan, sehingga mampu menjalin komunikasi dengan mitra tutur dengan baik dan benar. Tolok ukurnya adalah adanya komunikasi yang sehat, santun, dan bermakna. Hal ini tentunya sesuai dengan situasi dan kondisi ketika tuturan itu berlangsung. Penelitian ini pda hakikatnya untuk mengetahui bagaimanakah tindak tutur antara komunitas prajurit TNI-AD Rindam XIV/Hasanuddin dalam penggunaan bahasa Indonesia dilihat dari fungsi kalimatnya.

Penelitian ini hanya membahas pada fungsi kalimat, hal ini menjadi perlu diungkap karena di dalam komunitas prajurit TNI-AD penggunaan kalimat ini ternyata dipetakan dalam beberapa situasi dan kondisi pada saat tuturan itu berlangsung. Keragaman tindak tutur yang berdasar pada fungsi kalimat di dalam komunitas prajurit TNI-AD sangat jelas perbedaannya dengan komunitas lain. Tuturan yang terbangun adalah tuturan yang karakteristiknya sangat berbeda, kuat, tegas, dan dibarengi dengan loyalitas dan hierarki yang mutlak harus diikuti.

Beberapa penelitian kajian sosiolinguistik dan sosiopragmatik terdahulu antara lain; (1) Gunawan (1983) membahas masalah sikap positif mahasiswa Fakultas Sastra Universitas Indonesia terhadap bahasa Indonesia ragam baku, (2) Moeliono (1988) membahas tingkat pendidikan 
masyarakat berpengaruh dalam usaha menumbuhkan sikap positif terhadap penggunaan bahasa Indonesia yang baku, (3) Mahmudah (2005) membahas sikap dan perilaku bahasa kelompok sosial menengah masyarakat kota Makassar terhadap penggunaan bahasa Indonesia ragam baku, (4) Marwiah (2011) membahas tindak tutur komunitas prajurit TNI dalam keluarga berdasarkan perspektif dan dampak sosio-psikologis perempuan. (5) Nuraidar Agus (2013) meneliti bentuk kesantunan linguistik dan strategi pertuturan bagi wanita dan pria etnis Bugis berdasarkan studi etika berbahasa berdasarkan konsep sosiopragmatik-jender. Penelitian-penelitian tersebut tidak secara langsung mencermati tindak tutur khususnya komunitasprajurit TNI-AD. Penelitian Marwiah mencermati tindak tutur komunitas TNI dalam keluarga, sehingga lebih didominasi tindak tutur antara komunitas prajurit TNI dan keluarganya bukan sesama anggota TNI itu sendiri.

Di dalam penelitian ini, penulis mengkaji tindak tutur antara komunitas prajurit TNI-AD Rindam XIV/Hasanuddin dalam penggunaan bahasa Indonesia, suatu tinjauan sosiopragmatik. Hal ini berdasarkan dari kenyataan di lapangan bahwa karakteristik berbahasa prajurit memiliki pola tertentu. Pola kebahasaan prajurit TNI-AD menawarkan bentuk yang sangat menarik.

\section{Metode Penelitian}

Penelitian ini berjenis penelitian deskriptif analisis dengan menggunakan pendekatan kualitatif. Melalui metode ini dapat diperoleh deskripsi yang luas, mendalam, tuntas, dan memiliki kredibilitas yang tinggi. Penelitian deskriptif ini dipilih untuk menganalisis, mengungkap, dan memberi gambaran secara menyeluruh mengenai tindak tutur Bahasa Indonesia komunitas TNI-AD Rindam XIV/Hasanuddin dilihat dari fungsi kalimat.

Penelitian ini didesain secara deskriptif kualitatif. Metode kualitatif berusaha memahami dan menafsirkan makna suatu tindak interaksi tingkah laku manusia dalam situasi tertentu menurut perspektif peneliti sendiri. Ciri penelitian deskriptif kualitatif adalah sumber data yang berupa natural setting. Data dikumpulkan secara langsung dari lingkungan nyata (natural setting) dalam situasi sebagaimana adanya, yang dilakukan oleh subjek dalam kegiatan sehari-hari.

Data penelitian ini adalah ujaran yang di dalamnya terdapat fungsi kalimat, yang muncul dalam tindak tutur antara komunitas prajurit TNI-AD Rindam XIV/Hasanuddin. Sumber data dalam penelitian ini adalah prajurit TNI-AD Rindam XIV/Hasanuddin yang berpangkat pamen, pama, bintara, dan tamtama diambil 18 orang. Teknik pengambilan sampel menggunakan purposive sampling. Sampel bermula dari populasi prajurit TNI-AD Rindam XIV/Hasanuddin yang berpangkat pamen 13 orang, pama 2 orang, bintara 2 orang, dan tamtama 1 orang. Sampel berjumlah 18 orang tersebut yang memenuhi kriteria penelitian.

\section{Analisis dan Pembahasan}

Pada bagian ini, akan diuraikan mengenai fungsi kalimat yang digunakan dalam peristiwa tindak tutur komunitas prajurit TNI-AD Rindam XIV/Hasanuddin yang terbagi menjadi tiga bagian yaitu (1) kalimat deklaratif, (2) kalimat interogatif, dan (3) kalimat imperatif. Kalimat deklaratif merupakan kalimat yang fungsinya hanya meminta pendengar atau yang mendengar kalimat itu untuk menaruh perhatian saja, tidak usah melakukan apa-apa, sebab maksud si pengujar hanya untuk memberitahukan saja. Kalimat interogatif adalah kalimat yang berfungsi agar pendengar 
atau orang yang mendengar kalimat itu untuk memberi jawaban secara lisan. Jadi yang diminta bukan hanya sekadar perhatian, melainkan juga jawaban. Sedangkan kalimat imperatif adalah kalimat yang berfungsi meminta agar pendengar yang mendengar kalimat itu memberi tanggapan berupa tindakan atau perbuatan yang diminta.

Tabel 3.1Data tindak tutur prajurit TNI-AD Rindam XIV/Hasanuddin dalam penggunaan bahasa Indonesia dilihat dari fungsi kalimat.

\begin{tabular}{lll}
\hline No. & Tindak Tutur & Kode Sumber Data \\
\hline 1 & Fungsi kalimat deklaratif: & \\
& $1.1 \quad$ kalimat deklaratif konstatif & DT TT FK 001-003 \\
& $1.2 \quad$ kalimat deklaratif performatif & DT TT FK 004-006 \\
\hline 2 & Fungsi kalimat interogatif & DT TT FK 007-010 \\
\hline 3 & Fungsi kalimat imperatif & DT TT FK 011-012 \\
\hline
\end{tabular}

Pembagian kalimat atas kalimat deklaratif, interogatif, dan imperatif adalah berdasarkan fungsi kalimat itu secara terlepas. Artinya, kalimat dilihat atau dipandang sebagai suatu keutuhan tertinggi. Kalimat dipandang pada tataran yang lebih tinggi, yakni dari tingkat wacana, maka kalimat tersebut dapat saja menjadi tidak sama antara bentuk formalnya dengan fungsinya. Ada kemungkinan sebuah kalimat deklaratif atau kalimat interogatif tidak lagi berisi pernyataan atau pertanyaan, tetapi berfungsi perintah.

Kalimat deklaratif yang digunakan dalam tindak tutur komunitas Prajurit TNI-AD Rindam XIV/Hasanuddin dibagi menjadi dua yaitu (a) kalimat konstatif, dan (b) kalimat performatif. Kalimat konstatif merupakan kalimat yang berisi pernyataan belaka. Sedangkan kalimat performatif adalah kalimat yang berisi perlakuan. Artinya, kalimat yang diucapkan oleh si pengujar berisi apa yang dilakukannya.

Adapun data terkait fungsi kalimat yang digunakan dalam tindak tutur Prajurit TNI-AD Rindam XIV/Hasanuddin sebagai berikut:

\section{Fungsi Kalimat Deklaratif}

Kalimat deklaratif konstatif

Pada peristiwa tutur Prajurit TNI-AD Rindam XIV/Hasanuddin, banyak sekali tindak tutur yang menggunakan kalimat deklaratif. Kalimat ini ditandai dengan maksud dan tujuan pembicara terhadap pendengar untuk menaruh perhatian saja, tidak usah melakukan apa-apa. Sehingga, lawan bicara atau yang mendengar kalimat tersebut tidak melakukan tindakan apa-apa kecuali memusatkan perhatian pada apa yang diucapkan oleh pembicara. Berikut ini beberapa kutipan yang menjelaskan fungsi kalimat ini:

Situasitutur: di dalam ruangan pada saat rapat persiapan kunker RI 2.

\section{Data TT FK 001}

“...kita sudah dikonfirmasi/di-contect sama pak dandim, nanti kita akan menyebar/pertebal TNI dan Polri terutama untuk yang ditengah yaitu untuk mengantisipasi keramaian..." (S 4)

Peristiwa tutur pada kutipan data TT FK 001 di atas adalah pembicara memberikan informasi bahwa melalui dirinya telah diberitahukan atau dikonfirmasi oleh atau dari Pak Dandim untuk melakukan penyebaran/penebalan prajurit TNI dan Polri pada bagian tengah keramaian. 
Pada tindak tutur tersebut, pembicara tidak menghendaki adanya respon balik berupa tindakan dari pendengar karena fungsinya semata-mata untuk memberikan informasi kepada pendengar. Pendengar atau para prajurit yang mendengarkan informasi tersebut tidak melakukan apa-apa kecuali memberikan perhatian terhadap informasi yang disampaikan guna memahami isi pesan atau informasi tersebut.

Kutipan lain yang berisi kalimat deklaratif pada tindak tutur prajurit TNI-AD Rindam XIV/Hasanuddin sebagai berikut:

\section{Data TT FK 002}

“... Dari pagi dan sampai malam, mudah-mudahan ada hasilnya, berpikiran positif dan ikhlas dan habis itu segera kembali selanjutnya segera bawa antar istrinya atau mungkin disuruh berangkat atau mungkin disuruh pulang, di situ sudah nggak ada, bisa jadi gitu kan? Ya udah kalo gitu, terima aja. Kita mangkel, istri berangkat. Kita gak mangkel, istri berangkat juga, ya udah, berbagi duaaja, ya gitu kan, gimana? Ya ikhlas, $\quad$ kita harus berani dan jujur. Itu aja dari saya. Terima kasih." (S 1)

Tindak tutur pada kutipan data TT FK 002 di atas adalah pembicaraan seorang prajurit yang status kepangkatannya lebih tinggi daripada prajurit lainnya. Maksud dari pembicraan adalah mengungkapkan perasaan sekaligus sebagai nasihat kepada prajurit lainnya untuk bekerja dengan penuh tanggung jawab baik itu tugas sebagai anggota TNI maupun sebagai kepala rumah tangga. Aktivitas keseharian yang dilalui dari pagi hingga malam hari diharapkan mampu membuahkan hasil. Oleh karena itu, pembicara memberikan saran agar terus berpikir positif dan ikhlas dalam melaksanakan tugas sebagai anggota TNI. Di samping itu, deksripsi akan tugas sebagai kepala rumah tangga yang sering kali tidak sesuai dengan harapan juga disarankan untuk tetap sabar dan menerima dengan lapang dada.

Maksud dari tuturan tersebut adalah memberikan motivasi maupun nasihat kepada lawan bicara baik secara langsung maupun dalam bentuk deskriptif analogi tentang situasi profesi yang ditekuni sebagai anggota TNI. Karena maksudnya hanya berupa nasihat, maka pembicara hanya sekedar memberitahu kepada pendengar dan hanya mengharapkan perhatian bukan untuk mengggerakkan pendengar untuk melakukan suatu tindakan tindakan.

Contoh lain kutipan tindak tutur prajurit TNI-AD Rindam XIV/Hasanuddin yang menggunakan kalimat deklaratif sebagai berikut:

\section{Data TT FK 003}

"Kita memiliki tugas yang sangat penting dalam kunjungan kerja RI 2 dalam waktu dekat ini. Oleh karena itu, dibutuhkan kerja keras untuk mempersiapkan penyambutan serta pendampingan dari semua rangkaian kegiatan nantinya." (S 2)

Kuitpan data TT FK 003 di atas diunggkapkan dengan tujuan bahwa prajurit memahami fungsi dan tanggung jawab sebagai seorang prajurit serta hal apa yang harus dilakukan untuk melaksanakan fungsi dan tanggung jawab tersebut. Pada tindak tutur di atas, pembicara memberikan informasi berupa penegasan bahwa prajurit TNI-AD Rindam XIV/Hasanuddin memiliki tugas yang sangat penting dalam rangka kunjungan RI 2 dalam waktu dekat. Selanjutnya, pembicara memberikan nasihat dan motivasi agar prajurit melakukan kerja keras demi menyukseskan penyambutan dan pendampingan dari semua rangkaian kegiatan. Karena fungsinya hanya informatif, maka pada peristiwa tutur ini, pembicara hanya mengharapkan perhatian 
prajurit untuk mendengarkan penegasan informasi yang sebelumnya telah diketahui sehingga prajurit sebagai pendengar tidak melakukan apa-apa, cukup mendengarkan informasi tersebut.

Ketiga kutipan di atas diklasifikasikan kedalam kalimat deklaratif jenis konstatif. Pengkategorian ketiga kutipan tersebut ke dalam kalimat deklaratif konstatif karena kalimatkalimat tersebut hanya sebatas memberi informasi kepada pendengar tanpa melakukan apa-apa baik oleh pembicara itu sendiri maupun oleh pendengar.

Kalimat deklaratif performatif

Situasi tutur: di dalam ruangan pada saat rapat persiapan kunker RI 2.

\section{Data TT FK 004}

$$
\text { "Siap..." (S 4) }
$$

Kutipan data TT FK 004 di atas disampaikan oleh prajurit ketika mendapatkan perintah komando dari atasan. Tuturan tersebut bermaksud menyampaikan informasi mengenai keadaan diri prajurit yang siap melaksanakan perintah atau memahami perintah yang diberikan. Ketika tuturan ini digunakan, secara bersamaan prajurit juga melakukan tindakan berupa gerak tubuh dalam keadaan siap. Ini menandakan bahwa apa yang dituturkan oleh prajurit tersebut juga diaplikasikan atau dilakukan dalam bentuk gerak atau tindakan.

Situasi tutur: di dalam ruangan pada saat apel pagi siswa Secara Reguler.

\section{Data TT FK 005}

"Bisa saya lanjutkan?" (S 17)

"Lanjutkan!" (S 18)

"Cukup dengan melangkah saja" (S 17)

Kutipan data TT FK 005 di atas disampaikan oleh salah seorang Bintara pelatih pada saat apel. Tuturan tersebut digunakan dengan maksud memberitahukan kepada prajurit mengenai satu cara bertindak dalam melaksanakan tugas. Fungsi pembicaraan pada tuturan tersebut adalah prajurit memberikan perhatian atas informasi tersebut tetapi bukan dalam bentuk tindakan. Berbeda dengan pembicara, pada saat tuturan tersebut digunakan, pembicara secara bersamaan juga memeragakan apa yang dituturkan (melangkah).

\section{Data TT BK 006}

"Memang sebaiknya kita bertepuk tangan kalau ada teman yang berhasil melaksanakan tugas dengan baik. Itu merupakan salah satu bentuk penghargaan, iyakan? (S 16)

Kutipan data TT BK 006 di atas disampaikan oleh salah seorang komandan pada saat apel. Fungsinya hanya sekadar informatif saja, sehingga cukup dengan perhatian lawan bicara bukan dalam bentuk respon balik berupa tindakan. Situasi tutur yang terjadi pada kutipan di atas adalah pembicara menyampaikan informasi bahwa salah satu bentuk apresiasi yang baik terhadap orang lain ketika berhasil melaksanakan tugas adalah bertepuk tangan. Pada saat tuturan tersebut digunakan, pembicara juga secara bersamaan memeragakan hal yang sama yaitu "tepuk tangan".

\section{Fungsi Kalimat Interogatif}

Pada kegiatan komunikasi verbal, antara penutur dan lawan tutur terikat oleh kaidah konvensi bahwa komunikasi akan terjalin dengan baik jika ada kesepahaman timbal balik atau 
balas-membalas pesan dari rangkaian topik pembicaraan yang sama. Ketika seseorang berbicara dan menghendaki adanya jawaban, maka fungsi tuturan itu adalah interogatif. Fungsi tersebut akan tercapai ketika mitra tutur memberikan apa yang dikehendaki pembicara berupa tuturan balasan. Semua ragam tindak tutur dapat diklasifikasikan sebagai tindak tutur interogatif ketika apa yang dituturkan di awal mendapatkan respon balasan dari mitra tutur berupa tuturan pula, bukan tindakan perilaku. Ada beberapa jenis tuturan yang klasifikasi interogatifnya bersifat abstrak (hanya diketahui atau dikehendaki secara personal oleh penutur).

Berikut ini beberapa contoh tindak tutur yang menggunakan kalimat interogatif:

Situasi tutur: di dalam ruangan pada saat apel sore siswa Secara Reguler.

\section{Data TT BK 007}

“... Atas perintah komandan pelatih saya, sekali gerak, jadi jangan bergerak tanpa perintah saya. jelas ya?" (S 17)

“... Siap/sudah." (S 18)

Kutipan data TT BK 007di atas menjelaskan bahwa subjek 17 menjelaskan kepada prajurit (siswa) tentang perintah yang disampaikan oleh komandan kepada subjek 17. Diakhir tuturan di bubuhi dengan kalimat tanya. Lalu, subjek 18 menanggapi penjelasan tersebut [siap/sudah]. Dar1 tuturan pertama, jelas bahwa pembicara menghendaki jawaban mengenai klarifikasi jelas atau tidaknya informasi yang diberikan tersebut. Sehingga, jawaban yang timbul adalah pernyataan ya atau tidak atau siap.

Situasi tutur: di dalam ruangan pada saat rapat persiapan kunker RI 2.

\section{TTBK 008}

“... Nggak kebaca saya tuh."(S 1)

“... Siap!.” (S 4)

Peristiwa tutur yang terjadi pada kutipan data TT BK 008 di atas adalah subjek 4 memberikan laporan mengenai rancangan strategi kegiatan yang akan berlangsung pada saat kunjungan RI 2. Pelaporan disampaikan dengan menggunakan bantuan power point. Kemudian subjek 4 menyampaikan isi presentasi tersebut di depan peserta rapat. Namun, ditengah presentasi laporan, subjek 1 memberikan komentar terhadap tampilan presentasi tersebut. Menurutnya, presentasi tersebut tidak terbaca oleh subjek 1. lalu, subjek 4 memahami maksud dari subjek 1 untuk segera membesarkan tampilan presentasinya yang disertai dengan perintah oleh subjek 1 untuk membesarkan presentasi tersebut.

\section{Data TT BK 009}

“... Bisa ya." (S 1)

“... Kalau yang di Bone ada di Balai kota ada ada ada alat........" (S 2)

“... Hmmm didampingi yah?” (S 1)

“... Siap. Jadi Kami mendampingi di Balai kota." (S 2)

“... Ya petunjuk?'(S 2)

“... Kemudian yang di Maros ada di Angkatan Udara dengan personil food securitinya kemudian yang di Gowa food securitynya dari tim Keslap Kesdam kalau yang di kediaman beliau yang di Makassar di Jalan Haji Bau dari Balai POM Provinsi." (S 1) 
Tindak tutur representatif pertama yang berfungsi kalimat interogatif pada kutipan di atas adalah tuturan yang digunakan oleh subjek 2 [kalau yang di Bone ada di balaikota ada ada ada alat......] Konteks tuturan ini adalah subjek 2 menanggapi permintaan yang diberikan oleh subjek 1 sehingga subjek 2 memberikan penjelsan klarifikasi.

Selanjutnya, fungsi kalimat dalam tindak tutur representatif ke dua yaitu tuturan yang disampaikan oleh subjek 2 [Siap. Jadi....]. Tuturan tersebut adalah pernyataan yang menjelaskan tentang kesanggupan dan kesediaan subjek B untuk menjadi pendamping berdasarkan permintaan subjek 1.

Fungsi kalimat dalam tuturan representatif ke tiga dari kutipan di atas adalah tuturan yang disampaikan oleh subjek 2 [kemudian yang di Maros ada di angkatan udara dengan food securitinya kemudian yang di Gowa dari tim Keslap Kesdam VII kalau yang di kediaman beliau yang di Makassar di Jalan Haji bau dari food security POM Provinsi]. Konteks dari tuturan tersebut adalah subjek 2 memberikan penjelasan kepada subjek 1 mengenai keberadaan alat-alat food security yang terbagi di beberapa lokasi.

\section{Data TT BK 010}

"Baik jadi intinya 84 itu yang dimau di tampilkan oleh pemda supaya pakJK itu hanya membangun jembatan gitu?" (S 2)

"Siap." (S 8)

Konteks tuturan pada dialog di atas yaitu subjek 8 menyatakan [siap] setelah mendengarkan pertanyaan dari subjek 2. Tuturan [siap] oleh subjek 8 bermakna pembenaran terhadap pertanyaan yang diajukan oleh subjek 2 . Oleh karena itu, tuturan [siap] adalah bentuk pernyataan seperti pada tuturan representatif dalam kalimat interogatif.

\section{Fungsi Kalimat Imperatif}

Kalimat imperatif dalam sebuah tuturan ditandai oleh tanggapan berupa tindakan atau perbuatan dari pendengar terhadap apa yang dikehendaki oleh pembicara. Ketika pembicara mengatakan "tutup pintunya" kemudian pendengar melakukan apa yang dimaksud oleh pembicara, maka tuturan pembicara tersebut berfungsi sebagai kalimat imperatif. Berikut ini beberapa contoh kalimat imperatif yang terdapat pada situasi tutur prajurit TNI-AD Rindam XIV/ Hasanuddin:

\section{Data TT BK 011}

“...Masuk....” (S 2)

“... Ini rutenya. Kendalanya nanti di situ karena rutenya itu tidak terlalu jauh kalau kita bandingkan dengan jalanan yang sedang dibangun tapi sedang bermasalah. Proyek jalanan yang sedang dibangun merupakan proyek dari jalan provinsi. Jadi, kemarin terakhir seharusnya bulan 122014 sudah diresmikan. Proyek ini pembayarannya Agak terlambat sehingga kontraktor melapor ke Polda Kemudian dari Kejaksaan juga sudah menangani dan sudah melakukan penelitian masalahnya. Dari pihak Polres hanya mengambil data dan dari Polda membantu bagaimana proses pembangunan jembatan di sepanjang jalan tersebut sehingga antara kontraktor dengan dinas pekerjaan umum dan yang lain. " ( S 8)

“... Baik jadi intinya 84 itu yang mau yang akan di tampilkan oleh pemda supaya pak JK itu hanya membangun jembatan gitu." (S 2)

“... Siap." (S 8)

“... Ok begitu yah membangun jembatan harus maksudnya gimana?” (S 2) 
Pada saat rapat sedang berlangsung, seorang prajurit mengetuk pintu. Subjek 2 selaku pimpinan rapat memerintahkan prajurit tersebut untuk segera masuk membawa berkas yang diminta. Setelah itu, subjek 2 melanjutkan perbincangannya dengan subjek 8 yang membahas suatu masalah proyek pembangunan jembatan yang melibatkan Polda dan Kejaksaan. Selanjutnya, subjek 2 kembali menanggapi laporan dari subjek 8 dan memberikan pertanyaan yang maknanya berupa pemantapan maksud berupa penyimpulan laporan oleh subjek 8 . Setelah pertanyaan disampaikan, subjek 2 memberikan komentar berupa jawaban sepaham dengan pertanyaan tersebut. Lalu, subjek 2 kembali mengajukan pertanyaan.

Berdasarkan konteks tuturan di atas, tuturan yang disampaikan oleh subjek 2 yang memberikan perintah kepada prajurit yang mengetuk pintu untuk segera masuk ke dalam ruang rapat merupakan tindak tutur direktif fungsi kalimat imperatif. Tuturan yang berfungsi memberikan perintah adalah tindak tutur direktif. Tindakan yang dilakukan oleh prajurit yang mengetuk pintu setelah mendengarkan tuturan "masuk" adalah yang dikehendaki oleh pembicara. Oleh karena itu, tuturan "masuk" merupakan jenis kalimat yang berfungsi imperatif.

\section{Data TT BK 012}

“... Nggak kebaca saya tuh."(S1)

“... Siap!.” (S 4)

“... Besarkan!.” (S 1)

Peristiwa tutur yang terjadi pada kutipan di atas adalah subjek 1 memberikan laporan mengenai rancangan strategi kegiatan yang akan berlangsung pada saat kunjungan RI 2. Pelaporan disampaikan dengan menggunakan bantuan power point. Kemudian subjek 4 menyampaikan isi presentasi tersebut di depan peserta rapat. Namun, ditengah presentase laporan, subjek 1 memberikan komentar terhadap tampilan presentasi tersebut. Menurutnya, presentasi tersebut tidak terbaca oleh subjek 1. Lalu, subjek 4 memahami maksud dari subjek 1 untuk segera membesarkan tampilan presentasinya yang disertai dengan perintah oleh subjek 1 untuk membesarkan presentasi tersebut. Tindakan yang dilakukan oleh subjek 4 (membesarkan tampilan presentase power point merupakan isi tuturan yang dikehendaki oleh subjek 1. Sehingga tuturan “Nggak kebaca saya tuh!” dan "Besarkan!” adalah menggunakan fungsi kalimat imperatif.

Berdasarkan penelitian terlihat perbedaan register pada komunitas prajurit TNI-AD dengan komunitas lain. Penggunaan kalimat dalam tindak tutur prajurit TNI-AD Rindam $\mathrm{XIV/Hasanuddin} \mathrm{bukan} \mathrm{pada} \mathrm{tataran} \mathrm{struktural} \mathrm{atau} \mathrm{pengkajian} \mathrm{kalimat} \mathrm{berdasarkan} \mathrm{satuan} \mathrm{atau}$ pembentuknya, tetapi lebih pada ragam fungsi dari kalimat itu sendiri. Fungsi kalimat yang muncul dalam penelitian ini adalah kalimat deklaratif, kalimat interogatif, dan kalimat imperatif. Kalimat deklaratif berdasarkan maknanya dapat dibagi menjadi kalimat konstatif dan kalimat performatif. Kalimat interogatif meliputi tindak tutur direktif, komisif, dan deklaratif. Kalimat imperatif meliputi tindak tutur direktif, ekspresif, komisif, dan deklaratif.

Di sisi lain, adanya penyimpangan sistemik dari penggunaan bahasa Indonesia di komunitas TNI-AD Rindam XIV/Hasanuddin berdasarkan data yang terhimpun. Penyimpangan sistemik dalam pemakaian Bahasa Indonesia dalam penelitian ini ditinjau dari perspektif normatif kaidah Bahasa Indonesia yang baik dan benar memang dapat dikatakan salah. Akan tetapi, secara perspektif sosiolinguistik tidak ada penggunaan bahasa yang salah dalam sebuah interaksi 
komunikasi dalam sebuah komunitas. Suatu komunitas mempunyai karakteristeristik penggunaan bahasa didalam interaksi bahasanya. Hal tersebut tidak dapat dikatakan sebuah kesalahan akan tetapi lebih pada sebuah penyimpangan.

Penyimpangan tersebut terjadi secara berulang-ulang baik pada anggota komunitas strata kepangkatan tinggi hingga sampai pada anggota dengan strata kepangkatan rendah. Oleh karena itu, peneliti menyatakan bahwa situasi kebahasaan tersebut sebagai penyimpangan berbahasa yang sistemik. Artinya, penyimpangan tersebut bukanlah sesuatu yang tidak disengaja dan terjadi hanya sekali kemudian dapat diperbaiki, tetapi penyimpangan tersebut sudah menjadi kebiasaan/konvensi di dalam suatu komunitas. Pengalaman linguistik telah terbukti mempengaruhi persepsi bicara dalam berbagai cara(Clopper \& Pisoni: 2004).

Berdasarkan pengamatan pada berbagai situasi tutur di dalam komunitas prajurit TNI-AD Rindam XIV/Hasanuddin, peneliti menarik sebuah kesimpulan bahwa komunikasi di komunitas tersebut dibangun atas dasar kesepahaman dan kebermaknaan dengan mengusung etika tanpa memandang kebenaran struktur. Begitu pula dengan pilihan katanya. Hal inilah yang menjadikan banyaknya penyimpangan berbahasa yang ditemukan.

\section{Kesimpulan}

Berdasarkan pengamatan pada berbagai situasi tutur di dalam komunitas prajurit TNI-AD Rindam XIV/Hasanuddin, peneliti menarik sebuah kesimpulan bahwa komunikasi di komunitas tersebut dibangun atas dasar kesepahaman dan kebermaknaan dengan mengusung etika tanpa memandang kebenaran struktur. Begitu pula dengan pilihan katanya. Hal inilah yang menjadikan banyaknya penyimpangan berbahasa yang ditemukan. Analisis protokol pengarahan misi dan pembekalan dalam brigade lapis baja menunjukkan bahwa sebagian besar interaksi terkait tugas didasarkan pada bahasa skrip (misalnya Kata kerja dan frasa tindakan yang menandakan metascript tertentu dan kemungkinan yang relevan). Protokol-protokol ini menunjukkan bahwa prajurit yang dilatih skrip menafsirkan misi kompleks sebagai kombinasi 15 meta-skrip yang dapat dipertukarkan, mengurangi tuntutan kognitif atau variasi yang diperlukan untuk proporsi yang dapat dikelola (Zohar \& Luria: 2003).

Di dalam kaitannya dengan fungsi kalimat, kalimat yang terbangun adalah kalimat yang menggunakan tindak tutur yang berfungsi membentuk kalimat deklaratif, kalimat interogatif, dan kalimat imperatif. Kalimat interogatif adalah kalimat yang berfungsi meminta agar pendengar atau mitra tutur memberi jawaban secara lisan. Jadi, yang diinginkan dari pengujar bukan hanya sebatas perhatian tetapi berupa jawaban. Ragam tindak tutur dapat diklasifikasikan sebagai tindak tutur interogatif ketika apa yang dituturkan di awal mendapatkan respons balasan dari mitra tutur berupa tuturan pula, bukan tindakan perilaku. Kalimat interogatif dijumpai pada tindak tutur direktif, komisif, dan deklaratif. Tindak tutur yang tampak pada kalimat interogatif ini menjadi hal yang sangat penting di dalam komunitas prajurit TNI-AD, ada indikasi yang sangat tidak baik berkaitan dengan disiplin dan loyalitas ketika kalimat interogatif ini tidak mampu menjembatani komunikasi yang baik. Kalimat imperatif adalah kalimat yang berfungsi meminta tanggapan berupa tindakan atau perbuatan dari pendengar terhadap apa yang dikehendaki oleh pembicara. Jenis kalimat ini dapat dijumpai pada tindak tutur direktif (menyuruh, meminta, dan memohon), ekspresif (meminta maaf), dan deklaratif (memutuskan dan membatalkan). Kalimat imperatif ini, 
menjadi hal yang tidak dapat ditawar dalam tuturan yang terbangun di komunitas prajurit TNI-AD karena tuturan yang berupa perintah menuntut prajurit untuk tunduk dan taat menjalankannya.

\section{Daftar Rujukan}

Agus, Nuraidar. 2013. Bentuk Kesantunan Linguistik dan Strategi Pertuturan Bagi Wanita dan Pria Etnis Bugis (Studi Etika Berbahasa Berdasarkan Konsep Sosiopragmatik-Jender). Disertasi. Ujung Pandang. Universitas Hasanuddin.

Alwasilah, A. Chaedar. 1993. Pengantar Sosiolinguistik Bahasa. Bandung: Angkasa.

Alwi, Hasan, dkk. 1999. Tata Bahasa Baku Bahasa Indonesia (Edisis Ketiga). Jakarta: Balai Pustaka.

Aslinda, dkk. 2007. Pengantar Sosiolinguistik. Bandung: Refika Aditama.

Badudu, J.S. 1993. Cakrawala Bahasa Indonesia 1. Jakarta: Gramedia Pustaka Utama. 1994. Inilah Bahasa Indonesia yang Benar II. Jakarta: Gramedia Pustaka Utama.

Bintaldam Vll/Wirabuana. 1975. Sejarah Kodam Vll/Wirabuana. Makassar: Bintaldam Vll/Wirabuana.

Bogdan, Robert C., Biklen. 1982. Knopp Sari. Qualittive Research For Education: An Introduction to Theory and Methods. Boston London: Allyn and Bacon.

Canale, Michael. 1983. "From Communicative Competence to Communicative Pedagogy". London: Longman

Chaer. Abd. 2004. Sosiolinguistik: Perkenalan Awal. Jakarta: Rineka Cipta.

Clopper, C. G., \& Pisoni, D. B. (2004). Homebodies and army brats: Some effects of early linguistic experience and residential history on dialect categorization. Language Variation and Change, 16(1), 31-48. https://doi.org/10.1017/S0954394504161036

Hudson, R.A. 1995. Sosiolinguistik. Diterjemahkan oleh Rochayah dan Misbach Djamil. Jakarta: Pusat Pembinaan dan Pengembangan Bahasa Departemen Pendidikan dan Kebudayaan.

Ibrahim, Abd. Syukur. 1993. Kajian Tindak Tutur. Surabaya: Usaha Nasional.

Labov, William. 1972. Sociolinguistic Patterns. Philadelphia: University of Pennsylvania Press.

Leech, Geofrey. 1993. Prinsip-Prinsip Pragmatik. Jakarta: Universitas Indonesia.

Mahmudah. 2005. "Sikap dan Perilaku Bahasa Kelompok Sosial Menengah Masyarakat Kota Makassa terhadap Penggunaan Bahasa Indonesia Ragam Baku: Pendekatan Jender". Disertasi. Ujung Pandang. Universitas Hasanuddin.

Marwiah. 2011. Tindak Tutur Komunitas TNI dalam Keluarga Berdasarkan Perspektif dan Dampak Sosio-Psikologis Perempuan (Studi Kasus pada Istri Komunitas TNI di Kodim 1412 Kolaka). Disertasi. Makassar. Universitas Negeri Makassar.

Moeliono, Anton M. 1988. Tata Bahasa Baku Bahasa Indonesia. Jakarta: Balai Pustaka.

Moleong. Lexy J. 2008. Metodologi Penelitian Kualitatif. Bandung: Rosdakarya.

Nababan, P. W. J. 1984. Sosiolinguistik: Suatu Pengantar. Jakarta : PT Remaja Rusdakarya.

Prasetya, Tutut. Bentuk, Makna, dan Fungsi Register TNI-AD di Bekangdam V Brawijaya Surabaya: Suatu Kajian Sosiolinguistik. Jurnal Digital Unair.

Sugiyono. 2009. Metode Penelitian Kuantitatif Kualitatif dan R\&D. Bandung: Alfabeta.

Sumarsono. 2008. Sosiolinguistik. Yogyakarta: Pustaka Pelajar.

Taha, Zainuddin. 2008. Gapura Bahasa: Kumpulan Makalah Pilihan tentang Bahasa dan Pengajaran Bahasa. Makassar: UNM.

Tarigan, Henry Guntur. 1990. Pengajaran Pragmatik. Bandung: Angkasa.

Trudgill, Peter. 1974. Sosiolinguistics An Introduction. Harmondsworth: Pinguin books, Ltd.

Wijana, I Dewa Putu. 1996. Dasar-Dasar Pragmatik. Yogyakarta: Andi Yogyakarta.

Yule, George. 2006. Pragmatik. Diterjemahkan oleh Indah Fajar Wahyuni. Yogyakarta: Pustaka Pelajar. 
Zohar, D., \& Luria, G. (2003, November). Organizational meta-scripts as a source of high reliability: The case of an army armored brigade. Journal of Organizational Behavior. https://doi.org/10.1002/job.216 